\title{
Externalities of Urban Renewal: A Real Option Perspective
}

\author{
K W Chau* and S K Wong
}

Revise May 8, 2012

\section{Suggested Citation:}

Chau, K. W. and Won, S. K. (2014) "Externalities of Urban Renewal: a Real Option Perspective" Journal of Real Estate Finance and Economics, 48(3), 546-560.

URL: http://link.springer.com/article/10.1007\%2Fs11146-013-9418-z

DOI: 10.1007/s11146-013-9418-z

*Please send comments to:

K.W. Chau

Department of Real Estate and Construction, The University of Hong Kong

Pokfulam Road

Hong Kong 


\title{
Externalities of Urban Renewal: A Real Option Perspective
}

\author{
K.W. Chau* \\ Ronald Coase Centre for Property Rights Research, The University of Hong Kong, Hong Kong \\ S.K. Wong \\ Ronald Coase Centre for Property Rights Research, The University of Hong Kong, Hong Kong
}

\begin{abstract}
If carefully planned, urban renewal may play an important role in regenerating a decaying neighborhood and mitigating the negative externality generated by dilapidated buildings in densely populated areas. Despite its potential benefits, in urban areas dominated by high-rise developments, urban renewal has an unintended negative impact on nearby properties since it reduces their redevelopment option values.

In this study, we develop a number of hypotheses on how an urban renewal project, once made known to the public, affects neighborhood housing prices and test them with data in Hong Kong. Our empirical findings suggest that the degree of positive externalities brought by urban renewal depends on the scale of an urban renewal project, as well as the amount of commercial areas included in the project. Most importantly, through examining changes in the age coefficient, we found that an urban renewal project reduces the value of nearby buildings beyond the boundaries of the project. The negative effect was stronger for older buildings and for those buildings located closer to the project's boundaries. These unintended consequences of urban renewal have not been analyzed or tested in previous studies.
\end{abstract}

Keywords: Age effect, externality, redevelopment option, transaction cost, urban renewal.

\footnotetext{
*Please send comments to:

K.W. Chau

Department of Real Estate and Construction, The University of Hong Kong

Pokfulam Road

Hong Kong
}

Acknowledgements: We are very grateful to an anonymous referee, Edward Coulson, Dogan Tirtiroglu, and participants of the Asia-Pacific Real Estate Research Symposium for their useful comments on and suggestions for our paper. We would also like to thank Amber P. S. Leung and Daniel Y. F. Lo for their assistance in data collection. 


\section{EXTERNALITIES OF URBAN RENEWAL: A REAL OPTION PERSPECTIVE}

\section{Introduction}

A neighborhood is a physical and social environment where people interact with each other and share a collective identity. If one maintains his / her property well, his / her neighbors would also benefit. If all residents in the neighborhood maintain their properties well, then everyone in it would benefit. However, this would not be the case if certain residents want to free-ride on the positive externality generated by well-maintained buildings. The consequence, as predicted by the Slumlords' Dilemma, is that a neighborhood would end up deteriorating because no one has an incentive to maintain his / her building for the benefit of others (Davis and Whinston, 1962). This situation is even worse in densely populated areas dominated by multiple ownership high rise buildings as high transaction cost prohibit negotiation among property owners to research a win-win solution. One solution for clearing a deteriorating neighborhood or slum is to have the government intervene and use its power of eminent domain to initiate urban renewal. However, in reality, urban renewal is not always well-received. For instance, the slum clearance projects in the U.S. during the 1960s - nicknamed the Federal Bulldozer - were viewed with extreme skepticism (e.g. Anderson, 1964). In Beijing, China, many migrant workers were made homeless when the slums ("urban villages") they lived in were cleared for the Olympics. ${ }^{1}$

Since property is immobile and durable, its price can be used as an indirect channel through which a neighborhood's quality is captured and revealed. For example, properties with pleasant views are known to command higher prices (Benson et al., 1998), which could be as much as $37 \%$ of a property's total value (Bourassa et al., 2004). Well-managed open spaces and parks are other positive neighborhood attributes. Well-managed parks can raise property prices by as much as $20 \%$, while poorly managed ones can depress prices by up to the same amount (Hendon, 1971). Despite increased levels of noise and air

\footnotetext{
${ }^{1}$ See “China's migrant workers: No place to call home," The Economist, Jun $7^{\text {th }}, 2007$.
} 
pollution, a property's proximity to major transportation facilities is generally valued positively (Poon, 1978; Chau and Ng, 1998). Yiu and Wong (2005) found that housing prices were even able to reflect the expectations of a neighborhood's residents of a new tunnel to their area well before its completion.

This paper seeks to examine how urban renewal project affects property prices in the neighborhood area (i.e. those outside of the urban renewal boundaries). Unlike the well-established neighborhood attributes examined in the preceding studies, urban renewal is much more controversial in nature and, as we will discuss shortly, could have unintended consequences on the redevelopment option value of nearby buildings. Some studies showed that large scale improvement or redevelopment projects increased the values of properties in the vicinity, especially in low-income neighborhoods (Rosenthal and Helsley, 1994; Immergluck, 2009). Other studies, however, did not find any positive price impact from urban renewal projects. Tse (2001) argued that only redeveloped buildings enjoyed better environments and higher economic values, not those in their neighborhood. This was later supported by Lai et al.'s (2007) empirical study, which found no significant price spillover effect from urban renewal projects to neighborhood residential properties. Therefore, the neighborhood effects due to urban renewal remain inconclusive.

To understand the conflicting results, the sources of external effects of urban renewal need to be identified and analyzed separately. First, the demolition of old and deteriorated buildings should reduce their negative externalities, such as health and safety hazards, to the neighborhood. Second, the replacement of older buildings with amenities, such as open public spaces, should produce positive externalities for the neighborhood. Sirpal (1994), for example, found that shopping malls enhanced the value of surrounding residential properties; the larger the shopping mall, the bigger the price effect. Third, if older buildings were redeveloped into residential buildings, the increase in supply could well depress the prices of nearby housing units. As a result, urban renewal does not necessarily produce positive externalities, which depend on the types of new building or facility to be built. In addition, an urban renewal project needs to be well-planned so that it fits into the surrounding urban landscape. 
One last possible neighborhood effect that has rarely been explored is that urban renewal could reduce the redevelopment option value of buildings outside an urban renewal project's boundaries. This arises from the fact that urban renewal boundaries are typically set for long periods of time and typically do not emanate outwards from their original boundaries in densely populated areas. In addition, urban renewal priorities are typically are set for districts rather than individual sites on an ad hoc basis. The presence of an urban renewal project in an area indicates that not just the site being redeveloped but the surrounding areas have also been studied. Therefore, after an urban renewal project in an area has been approved, the chance that the government will initiate another urban renewal project in the same area will be significantly reduced. In the traditional decision-making framework, redevelopment should take place when the replacement value exceeds the sum of the use value of an existing building and the redevelopment costs (Brueckner, 1980; Rosenthal and Helsley, 1994; Munneke, 1996). The real option theory adds that in addition to the current use value, existing buildings also carry a non-negative real option for the flexibility to redevelop into higher intensity or alternative uses (Clapp et al., 2007). As a building ages, its use value decreases, while its option value increases (Clapp and Salavei, 2010; Clapp et al., 2012). For multiple ownership buildings, this option value is also affected by the transaction cost of negotiation amongst owners of the units in the building. Urban renewal can lower this transaction cost. However, if a building is excluded from a nearby urban renewal project, its redevelopment option value will decline as the chance it being included in another urban renewal project will decrease significantly. We will test if the value of redevelopment options embedded in nearby buildings diminishes as a result of urban renewal.

Cases in Hong Kong will be used to test the various neighborhood effects of urban renewal. Hong Kong is a good place to study redevelopment value because of its high population density, limited land supply, aging building stock, and popularity of multiple ownership high-rise buildings. Section 2 provides a background of urban renewal in Hong Kong. Section 3 discusses the theoretical background and develops testable hypotheses on changes in the age coefficient after a public announcement of an urban renewal project's boundaries. Section 4 shows the empirical model and data for testing the hypotheses. 
Section 5 presents the results and their implications. Section 6 concludes the study with policy and practical implications.

\section{Urban Renewal in Hong Kong2}

Hong Kong's urban area has grown quickly in response to its changing economic and social demands. While its citizens have enjoyed the benefits of rapid economic growth over the years, problems associated with urban decay and aging buildings have also increased. There are now about 15,000 multiple ownership apartment buildings aged over 30 years in Hong Kong's urban areas, and this number is expected to increase by $50 \%$ to 22,500 in ten years (Urban Renewal Authority, 2008). Without proper maintenance, these buildings would deteriorate rapidly and become a burden to society. For instance, the collapse of a rundown five-storey residential building in 2010 killed four residents. ${ }^{3}$ This immediately led the government to pull down the older adjacent buildings and the nearby old buildings were designated as high priority urban renewal project.

The role of private developers in acquiring and redeveloping old properties is quite limited. This is because residential building units in Hong Kong are held under multi-ownership titles, $^{4}$ transaction costs of re-development is high. To acquire a residential building owned by many individuals, developers have to face the risk of holdout units, defective titles, and untraceable owners. To manage these risks, developers do not normally seek to comprehensively redevelop a large area, but rather small sites. Such a redevelopment scale often did not benefit the neighbourhood and even made comprehensive redevelopment of the whole area more complicated (Adams and Hastings, 2001) and potentially inefficient.

Given that private redevelopment is relatively limited and slow, government intervene to lower the transaction cost. The Urban Renewal Authority (URA), formerly the Land

\footnotetext{
2 In this study, urban renewal always refers to projects initiated by the public sector. Private sector projects are simply called redevelopment projects.

3 See "Fatal collapse due to 'external forces'," The Standard, April $27^{\text {th }}, 2010$.

${ }^{4}$ A multi-ownership title means the owner of a flat co-owns the whole multi-story building with other owners as a tenancy in common, while reserving the right to exclusively use his own flat (Nield, 1997).
} 
Development Corporation (LDC), is the major government agency involved in the urban renewal process in Hong Kong,. According to its homepage, the URA aims to address the problem of urban blight and improve the quality of neighborhoods by providing a cleaner environment and upgrading street designs and community amenities. What makes the URA superior to private developers is its statutory power to commandeer property free of title or holdout problems as long as reasonable compensation is paid to the owners. Some homeowners who lived in poorly-maintained buildings are indeed waiting for the URA to acquire their buildings and compensate them.

Because of its statutory power and public accountability, the URA's projects are generally larger and more comprehensive than those undertaken by private developers. Considering the positive externalities alone (see Introduction), an URA project should more likely benefit a neighborhood than a private one. The URA, however, is required to operate on commercial principles - its projects should not only benefit society, but also be financially sound. This has two effects on its site selection strategy. At the macro level, the URA may have an incentive to renew districts that appreciate at a faster rate than the rest of the city. At the project level, the URA may mark its urban renewal boundaries in such a way so as to ensure that the sites included are financially viable. Buildings outside the boundaries (i.e., those not targeted by the URA) would be accorded lower redevelopment priority and lose the chance to be acquired and compensated in the near future. It is not uncommon to hear complaints from homeowners who were excluded from URA projects. These complaints may well reflect the real option idea we mentioned earlier - urban renewal could have an unintended negative impact on nearby properties because their chances of being redeveloped are lowered. We will formulate hypotheses based on this idea in the next section.

\section{Development of Hypotheses}

This study makes use of the redevelopment projects initiated by the URA to study the impact the neighborhood effects on nearby residential properties. Borrowing the idea of Clapp et al. (2007), we model property value, P, as a sum of two components: 


$$
P=\text { use value }+ \text { value of option to redevelop }
$$

To focus on our main idea of neighborhood effects, we put Eq. (1) in its simplest form without the time dimension:

$$
P=p H+f\left(p\left(H^{*}-H\right)-C\left(H^{*}, H\right)-\kappa\right)
$$

where $\mathrm{H}$ is an aggregate index that measures the level of all housing services, including both the structural services and services from the neighborhood, which were obtained from one's residence in a property in a specific location; ${ }^{5} \mathrm{p}$ is the price per unit of housing services exogenously determined in the economy; $f($.$) is a non-negative function$ representing the option value to redevelop; $\mathrm{H}^{*}$ is the optimal level of housing services obtainable in the same location; $\mathrm{C}($.) is a cost function for demolishing $\mathrm{H}$ and constructing $\mathrm{H}^{*}$; and $\mathrm{K}$ is the transaction cost in assembling the properties for redevelopment (title assembly cost). $\mathrm{H}^{*}$ must be greater than $\mathrm{H}$ for any option value to exist.

The first term, $\mathrm{pH}$, is simply the hedonic function of existing characteristics: a higher level of housing services would lead to a higher use value (i.e., $\partial$ (use value)/ $\partial H=p>0$ ). The second term captures the option to redevelop the existing property into its optimal configuration when the replacement value, $\mathrm{pH}^{*}$, exceeds the value of the existing property, $\mathrm{pH}$, plus the demolition, construction, and title assembly costs, i.e. $\mathrm{C}\left(\mathrm{H}^{*}, \mathrm{H}\right)+\mathrm{K}$. In an economy where land cost is a lot higher than construction cost, $\mathrm{p}\left(\mathrm{H}^{*}-\mathrm{H}\right)$ is much more important than $\mathrm{C}\left(\mathrm{H}^{*}, \mathrm{H}\right)$ in determining the option value. In particular, $\partial$ (option value)/ $\partial \mathrm{H}^{*}$ $>0$ and $\partial$ (option value) $/ \partial H<0$. We add the title assembly cost, $\mathrm{k}$, to the strike price of the option term because unlike single-family houses analyzed by Clapp and Salavei (2010) and Clapp et al. (2012), the redevelopment of multiple ownership apartment buildings would be

\footnotetext{
${ }^{5}$ As Zabel (2004) pointed out, what constitutes housing services is ambiguous in the literature. Some include only the structure services (e.g. footage), while others also include services in the neighborhood (e.g. local amenities). This study follows the latter definition, so a change in neighborhood characteristics would result in a change in $\mathrm{H}$.
} 
impossible without assembling all or a majority ${ }^{6}$ of the titles of apartment units in the first place. A higher $\mathrm{k}$ would lower the option value and property price (i.e., $\partial \mathrm{P} / \partial \mathrm{\partial}<0$ ).

Then we formulate hypotheses for various neighborhood effects based on Eq. (2). We are particularly interested in comparing the external effects of urban renewal on newer and older buildings because the option value term in Eq. (2) becomes more important when a building ages (Clapp and Salavei, 2010; Clapp et al., 2012).

Suppose newer and older buildings provide different levels of housing service denoted respectively by $\mathrm{H}_{\text {new }}$ and $\mathrm{H}_{\text {old }}$. Due to depreciation and obsolescence, $\mathrm{H}_{\text {new }}$ is usually larger than $\mathrm{H}_{\text {old }}$. The level of housing services given by a brand new building should be close to the optimal (i.e., $\mathrm{H}_{\text {new }} \rightarrow \mathrm{H}^{*}$ ), so we assume a new building has no option value and its price can be solely described by its use value:

$$
P_{\text {new }}=p H_{\text {new }}
$$

On the other hand, an older building's service level normally falls below the optimal and therefore its redevelopment option value cannot be ignored. The price of an older building is the sum of its use and option values, with $\mathrm{H}_{\text {new }}$ replacing $\mathrm{H}^{*}$ in Eq. (2):

$$
P_{\text {old }}=p H_{\text {old }}+f\left(p\left(H_{\text {new }}-H_{\text {old }}\right)-C\left(H_{\text {new }}, H_{\text {old }}\right)-\kappa\right)
$$

What would be the external effects on a building if urban renewal takes place in its neighborhood? We hypothesize three effects. The first two effects are independent of

\footnotetext{
${ }^{6}$ Before 1999, a developer has to have $100 \%$ shares of the equity interests of an apartment building in order to redevelop it. Since 1999, the Land (Compulsory Sale for Redevelopment) Ordinance (LCSRO) (Cap. 545) provides that a person who owns not less than $90 \%$ equity interests of an apartment building can apply to the Lands Tribunal for a compulsory sale (by auction) of the whole building for the purpose of redevelopment. In 2010, the threshold was further lowered to $80 \%$ for residential buildings older than 50 years and for buildings in which each unit represents more than $10 \%$ of the equity interest of the entire building.
} 
the option value term, while the last one is an "unintended consequence" drawn from Eqs.(3) and (4).

First, urban renewal would improve a neighborhood's quality by reducing its negative externalities (e.g. removing unattractive and dilapidated buildings). The improvement in neighborhood quality is reflected in our model by a higher level of housing services, $\mathrm{H}$. We assume that both $\mathrm{H}_{\text {new }}$ and $\mathrm{H}_{\text {old }}$ increase by the same amount, as there is no a priori knowledge that newer or older properties should benefit more. As a result, for both newer and older buildings, only the use value term matters. ${ }^{7}$ The increase in use value depends on the change in the magnitude of $\mathrm{H}$, which, in turn, varies with the scale of urban renewal. The larger the redevelopment area, the greater the neighborhood improvement. Hence, the increase in $\mathrm{H}$ would be greater. This produces a higher property value $(\partial \mathrm{P} / \partial \mathrm{H}>0)$ and leads to our first hypothesis:

H1: Nearby properties benefit more from larger scale urban renewal projects.

If this hypothesis is true, larger redevelopment projects would give rise to a stronger value enhancement effect on surrounding properties.

Second, urban renewal could also bring in positive externalities (e.g. shopping malls and public spaces). Residents in the neighborhood could enjoy more shopping and social interaction opportunities upon the completion of the redevelopment. Similar to the logic in $\mathrm{H} 1$, the provision of commercial facilities would give rise to a higher level of housing services, $H$, and enhance nearby residential property prices $(\partial P / \partial H>0)$. Therefore, our second hypothesis is:

H2: Nearby residential properties benefit more from urban renewal projects with a larger commercial component.

If this hypothesis is true, redevelopment projects with more commercial areas would have a stronger value enhancement effect on surrounding properties.

\footnotetext{
7 In Eq. (4), if $\mathrm{H}_{\text {new }}$ and $\mathrm{H}_{\text {old }}$ increased by the same percentage and their increase had a negligible impact on $\mathrm{C}$, then the option value term would remain unchanged.
} 
Unlike $\mathrm{H} 1$ and $\mathrm{H} 2$, the final implication is the most interesting and perhaps counterintuitive, as urban renewal could adversely affect the option value of nearby buildings through two channels. First, these buildings lose the opportunity to enjoy synergy from being redeveloped jointly with the area targeted for urban renewal. Synergy arises from economies of scale when sites are combined to increase their development potential (e.g. higher maximum development density). Larger sites can also accommodate more common facilities and allow more flexible design, uses or configurations. For buildings excluded from an urban renewal project, even if they were redeveloped in the future, their optimal service level, $\mathrm{H}^{*}$, would not be as high as when synergetic opportunities were available and their option value to redevelop would thus be reduced.

The second and more important channel through which nearby buildings lose value is that urban renewal projects raises the expected title assembly cost of nearby buildings. Consider a situation in which title assembly is very costly (e.g. acquiring multiple-ownership titles in apartment buildings), which means that $\mathrm{K}$ is high. As mentioned in Section 2, a powerful government agent like the URA is usually welcomed by homeowners because its power of eminent domain can help lower $\mathrm{k}$ and, hence, unlock the option value of the properties included in its urban renewal projects. Let $\mathrm{K}_{U}$ and $\mathrm{K}_{\mathrm{p}}$ be the title assembly costs of the URA and private developers, respectively. Since the former has eminent domain power, $\mathrm{K}_{U}$ is smaller than $\mathrm{K}_{\mathrm{p}}$. Given that the probability of a building to be redeveloped by the URA is $w_{U}$, the expected land assembly cost can be stated as:

$$
\kappa=w_{U} \kappa_{U}+\left(1-w_{U}\right) \kappa_{P}
$$

Limited by its objective of self-financing, the URA has its own internal principles for determining, for each district, which buildings should be targeted or prioritized for urban renewal. Buildings not targeted have a lower $w_{U}$; they would not be redeveloped by the URA until higher priority projects in other districts are completed. The public does not know the URA's future targets, but whenever the URA announces its projects, the public would know that nearby buildings excluded from the plans are unlikely to be redeveloped in the near future. These buildings' $w_{U}$ will decline substantially, raising their expected title assembly costs towards $\mathrm{K}_{\mathrm{p}}$, according to Eq. (5). 
Comparing Eq. (3) with Eq. (4), the option value term is present in the older building only. Being excluded from a nearby urban renewal project implies a reduction in its redevelopment option value (either because of a reduction in $\mathrm{H}^{*}$ or an increase in $\mathrm{K}$. This leads to our third hypothesis:

H3: Urban renewal reduces the redevelopment option value of nearby properties.

If this hypothesis is true, urban renewal projects will depress the value of nearby older properties more than those of newer ones. Moreover, the negative impact due to loss in synergistic opportunities and a rise in title-assembly costs is more significant for buildings closer to an urban renewal project. Therefore, if $\mathrm{H} 3$ is correct, the negative impact on redevelopment options should be stronger for buildings that are situated closer to an urban renewal project.

\section{Research Design}

\subsection{Sample}

To measure the neighborhood effects stemming from urban renewal, it is necessary to collect records of property transactions in the immediate vicinity of the areas targeted for urban renewal. In this study, we chose the residential properties located within 200 meters (i.e., about $650 \mathrm{ft}$ ) of an urban renewal area. One reason for our confinement to such a small area is to capture the most direct effects brought about by urban renewal. A Pittsburgh case study suggests that "property will suffer significant external effects only from those features within one hundred and fifty feet of its boundaries" (Rueter, 1973, p.321). Another reason is that we want to better control for the locational factors that could affect the prices of a property. Limiting the sample to a small area would help us avoid the problem of omitted variable bias. 
Since Hong Kong has a highly liquid housing market (Chau et al. 2005), we were able to collect a sample of more than 40,000 condo sales records in the vicinity of the urban renewal projects performed by the URA in ten districts from 1991 to 2011. We have discarded pre-sales transactions since their prices do not reflect spot market clearing prices. We obtain the transaction data from $E P R C^{8}$, which provides not only the transaction prices of condo units registered at the Land Registry, but also key condo characteristics such as flat size, floor level, and building age.

To ascertain the timing of any urban renewal effect, we need to identify when an urban renewal project was announced. The first date of conducting the freezing survey is taken as the announcement date of an urban renewal project. ${ }^{9}$ The public, including affected owners, do not know about an urban renewal project before the URA conducted its freezing survey. ${ }^{10}$ Most of the announcement dates of the urban renewal projects aree collected from the URA's press releases, while the rest are found from local newspaper archives.

Other details about the urban renewal projects are obtained from the Legislative Council Panel Papers (e.g. Legislative Council, 2009). In these papers, the URA report its work progress and plans for the coming year to the Legislative Council. The project highlights include the size of each urban renewal site and the type and scale of the proposed new development, which are essential information for testing Hypotheses 1 and 2.

\subsection{The empirical Model}

8 EPRC is third party value added data provider that supplies electronic property information in Hong Kong including real estate transactions registered with the Land Registry of the Hong Kong SAR Government.

\footnotetext{
${ }^{9}$ Freezing surveys are a snapshot of the ownership, tenancy, and other legal rights surrounding the property to be redeveloped. They are conducted when an urban renewal project is first published in the Government Gazette.

${ }^{10}$ Hong Kong has a good reputation for its anti-corruption measures, so cases of leaking urban renewal targets are rare. According to the 2012 Index of Economic Freedom compiled by the Heritage Foundation and Wall Street Journal, Hong Kong received a score of 84 (world ranking: $13^{\text {th }}$ ) in Freedom from Corruption.
} 
To test the three hypotheses developed in Section 3, we estimate the following hedonic model using the ordinary least squares technique:

$$
\begin{aligned}
& \ln (R P)=\alpha_{0}+\alpha_{1} \ln (A G E)+\alpha_{2} \ln (G F A)+\alpha_{3} \ln (F L R)+\beta_{1} T+\beta_{2} T^{*} \text { SITE_SIZE } \\
& +\beta_{3} T^{*} \text { COM_SIZE }+\beta_{4} T^{*} \ln (A G E)+\beta_{5} T^{*} \ln (A G E) * D I S T+\lambda_{k}+\varepsilon
\end{aligned}
$$

where:

$R P=$ real property price in $\mathrm{HK} \$$ million (obtained by deflating nominal transaction prices by their corresponding district-level property price indices); ${ }^{11}$

$A G E=$ the age of the property in years;

$G F A=$ Gross Floor Area of the property (condo unit) in square feet;

$F L R=$ floor level of the property;

$T=$ an event dummy variable that equals 1 after the announcement of an urban renewal project and 0 otherwise;

SITE_SIZE = area of the site included in the urban renewal project $\left(\right.$ in $\left.\mathrm{ft}^{2}\right)$;

COM_SIZE $=$ commercial floor area (in thousands of $\mathrm{ft}^{2}$ ) created by the urban renewal project;

$D I S T=$ distance from the urban renewal project in feet;

$\lambda_{k}=$ a set of nine location dummies indicating the district in which the urban renewal project is located;

$\alpha_{i}$ and $B_{j}=$ coefficients to be estimated; and

$\varepsilon=$ error term

\footnotetext{
11 The price indices, known as HKU-REIS, were constructed using Bailey et al.'s (1963) repeat-sales method. See Chau et al. (2005) for more details.
} 
The first three variables, AGE, GFA, and FLR, are the structural characteristics of the property. These are the typical variables used for the hedonic analysis of condo unit prices. The measurement of floor area deserves some discussion because different definitions are adopted for Hong Kong. The most widely used definition is GFA, which consists of the internal floor area (IFA) of a unit and the communal floor area (CFA) shared by all units (e.g. a garden). If GFA is used, we have 42,473 valid usable transactions to estimate Eq. (6a). However, buyers may not value exclusively-owned space in the same way as shared space. We therefore also break GFA down to IFA and CFA as a robustness check:

$$
\begin{aligned}
& \ln (R P)=\alpha_{0}+\alpha_{1} \ln (A G E)+\alpha_{2} \ln (I F A)+\alpha_{3} \ln (C F A)+\alpha_{4} \ln (F L R)+\beta_{1} T+ \\
& \beta_{2} T^{*} \text { SITE_SIZE }+\beta_{3} T^{*} \text { COM_SIZE }+\beta_{4} T^{*} \ln (A G E)+\beta_{5} T^{*} \ln (A G E) * D I S T+\lambda_{k}+\varepsilon
\end{aligned}
$$

Since not all transaction records have information on both IFA and CFA, the sample size for estimating Eq. (6b) is reduced to 29,340 transactions.

The terms with $T$ are the focal points of this study. $T$ is a time dummy that indicates if a property was transacted before or after the announcement of an urban renewal project. Its coefficient, $\beta_{1}$, reflects the effects of any changes that affect nearby housing prices after an urban renewal project is made known to the public, which is not captured by the district-level price indices (for deflating RP) and location dummies $\left(\lambda_{k}\right)$. The changes mainly include externalities from urban renewal and may include some effects of the non-random selection of an urban renewal location. The latter comes from the notion that the URA bases its choice of urban renewal locations not only on societal needs, but also on financial considerations (see Section 2).

Other $\beta$ s are the parameters for testing the three hypotheses. First, the site area covered by an urban renewal project (SITE_SIZE) represents the magnitude of negative externalities before urban renewal. If the property market values the reduction in negative externalities (Hypothesis 1), the coefficient $\beta_{2}$ should be positive. Second, the commercial floor space created by an urban renewal project (COM_SIZE) represents the magnitude of positive externalities. If the property market values the provision of these positive 
externalities (Hypothesis 2), the coefficient $\beta_{3}$ should be positive. Third, according to Hypothesis 3, urban renewal should have a larger negative impact on older buildings (AGE), while the negative impact should be weakened if a building is situated farther away from the urban renewal site (DIST). If these are correct, the coefficient $\beta_{4}$ should be negative, while the coefficient $\beta_{5}$ should be positive. A summary of the expected sign of each coefficient is shown in Table 1.

[Table 1 about here]

\section{Empirical Results}

The summary statistics of our sample are shown in Table 2. Over the whole sample period, the average real (year 2000) price of a condo unit was HK\$1.724 million (equivalent to US\$221,000). The mean price increased by $4 \%$ (from HK\$1.691 to HK\$1.757 million) after an announcement of an urban renewal project. An "average" transacted condo unit has the following characteristics: 13 years old, $520 \mathrm{ft}^{2}$ large $\left(407 \mathrm{ft}^{2}\right.$ internal space and $136 \mathrm{sf}^{2}$ communal space), 13 floors above the ground level, and $416 \mathrm{ft}$ away from the concerned urban renewal project. This specification is quite standard for a two-to-four-person family in Hong Kong. Except for building age, the average characteristics are quite similar before and after an announcement.

[Table 2 about here]

The estimated results of the hedonic equations in Eqs.(6a) and (6b) are presented in Table 3. Both have an adjusted R-squared of $83 \%$, which is similar to the R-squared reported in other hedonic studies of condo units. Indeed, both sets of results are highly similar, so how condo unit size is measured does not matter in this study. The results of both equations will be discussed together unless otherwise specified.

[Table 3 about here]

All estimated coefficients of the structural attributes are statistically significant at the $1 \%$ level. These coefficients represent the implicit prices of these attributes before any urban 
renewal effects (i.e., $T=0$ ). As expected, real property prices decrease with building age, but increase with the condo unit's size and floor level. A $10 \%$ increase in building age reduces property prices by $0.7 \%$, which roughly corresponds to a $0.54 \%$ annual depreciation for a building of average age in our sample. A $10 \%$ increase in flat size raises property prices by $11 \%$; an extra square foot for an average-sized unit cost about $H K \$ 4,500$. In Eq. (6b), when the gross floor area is broken down into internal and communal areas, we found that the implicit price of internal area (elasticity $=0.969$ ) is almost ten times that of communal area (elasticity $=0.110$ ). $\mathrm{A}$ higher value is therefore attached to exclusively-owned space. As for floor level, a $10 \%$ increase raises property prices by about $0.8 \%$. This is consistent with the magnitude found in other hedonic studies on Hong Kong (e.g. Wong et al. 2011).

Next, we turn to the coefficients concerning the urban renewal effects (i.e., $T=1$ ). Consider an average property in our sample. An announcement of an urban renewal project increases neighborhood property prices by an average of $4.0 \%$ (Eq.6a) and 3.4\% (Eq.6b). ${ }^{12}$ The coefficients of the two interaction variables, T*SITE_SIZE and T*COM_SIZE, are positive and significant at the $1 \%$ level. ${ }^{13}$ For a $10,000 \mathrm{ft}^{2}$ increase in the site area of an urban renewal project, neighborhood property prices increases by $0.6 \%$. On the other hand, for a $10,000 \mathrm{ft}^{2}$ increase in the commercial area of an urban renewal project, neighborhood property prices increase by $0.9 \%$ (Eq.6a) and $1.3 \%$ (Eq.6b). The results show that the property values capitalize both the reduction in negative externalities and the addition of positive externalities arising from nearby urban renewal projects, with the latter being more valuable in our sample. These results are consistent with the predictions of $\mathrm{H} 1$ and $\mathrm{H} 2$.

Finally, we assess whether urban renewal has a negative impact on redevelopment option value of nearby properties. The coefficients of the last two interaction variables, $T^{*} \ln (\mathrm{AGE})$

\footnotetext{
12 Since T enters the equations on its own, as well as with other variables, its effect includes not just the coefficient on $\mathrm{T}$, but also the coefficients of its interactive terms.

13 We used the White heteroskedasticity-consistent standard errors. If clustered robust standard errors are used, the two coefficients would become insignificant. We take this as a caveat to readers.
} 
and $T^{*} \ln (A G E) * D I S T$, are negative and positive, respectively. They are both significant at the $1 \%$ level. ${ }^{14}$ This suggested that the older housing units depreciate faster after the announcement of an urban renewal project. For a $10 \%$ increase in building age, property prices depreciate by $1.2 \%$, which is larger than the $0.7 \%$ depreciation before the announcement of an urban renewal project. ${ }^{15}$ Moreover, older buildings closer to the site of an urban renewal project show greater price depreciation. With respect to a property with an average building age, a 100-ft decrease in distance from an urban renewal project lower its property price by $1.3 \%$ (Eq.6a) and $0.6 \%$ (Eq.6b). These results, therefore, confirm the empirical implications of $\mathrm{H} 3$ : urban renewal project has stronger negative impact on the values of older units than those of newer nearby buildings and that such impact diminishes as distant from the urban renewal project increases.

\section{Conclusion}

A well-planned urban renewal project in a densely populated areas dominated by high-rise developments may have a positive external effect on its neighborhood area, as it helps to reduce the negative externalities posed by dilapidated buildings. Besides, urban renewal may create a better environment and introduce new amenities into a community. These positive externalities would be reflected in higher property values in the neighborhood of the urban renewal project.

However, after breaking down the property values into their current uses and redevelopment option components, we found that urban renewal projects actually generates two opposite effects on nearby properties values. On the one hand, the impact on the current use value is positive and that the impact is stronger for larger urban renewal projects and for projects with more commercial facilities. On the other hand, the impact

14 We used the White heteroskedasticity-consistent standard errors. Their coefficients are still significant at the $1 \%$ and $10 \%$ levels when clustered robust standard errors are used.

15 The $1.2 \%$ figure was calculated with respect to a building located at an average distance from the urban renewal project. 
on the redevelopment option value is negative since the nearby buildings are, by definition, excluded from the urban renewal project. We hypothesize that the negative impact mainly arises from the high transaction costs of redeveloping a multiple-ownership of high-rise buildings, which can be most easily overcome by government led initiatives such as urban renewal. In addition, the nearby buildings, even if redeveloped by private developers in the future, would not be able to enjoy the scale effect of being redeveloped together with the nearby urban renewal project. This negative externality of urban renewal has rarely been considered in any economic impact analysis of urban renewal projects; therefore any positive externality brought about by urban renewal might have been overestimated. Our study also provides an economic explanation for why owners of older units may be disappointed when a nearby urban renewal project is announced. 


\section{REFERENCES}

Adams, D. and Hastings, E.M. (2001), "Urban renewal in Hong Kong: transition from development corporation to renewal authority," Land Use Policy, 18, pp.245-258.

Anderson, M. (1964) The Federal Bulldozer: A Critical Analysis of Urban Renewal, 1949-1962, M.I.T. Press: Cambridge, Mass.

Bailey, M.J., Muth, R.F. and Nourse, H.O. (1963), "A regression method for real estate price index construction," Journal of the American Statistical Association, 58, 304, pp.933-942.

Benson, E.D., Hansen, J.L., Schwartz, A.L. Jr., and Smersh, G.T. (1998), "Pricing residential amenities: The value of a view," Journal of Real Estate Finance and Economics, 16, 1, pp.55-73.

Bourassa, S.C., Hoesli, M. and Sun, J. (2004), "What's in a view," Environment and Planning A, 36, 8, pp.1427-1450.

Brueckner, J.K. (1980), "A vintage model of urban growth," Journal of Urban Economics, 8, 3, pp.389-402.

Chau, K.W. and Ng, F.F. (1998), "The effects of improvement in public transportation capacity on residential price gradient in Hong Kong," Journal of Property Valuation and Investment, 16, pp.397-410.

Chau, K.W., Wong, S.K., Yiu, C.Y. and Leung, H.F. (2005), "Real estate prices indices in Hong Kong," Journal of Real Estate Literature, 13, 3, pp.337-356.

Clapp, J.M. and Salavei, K. (2010), "Hedonic pricing with redevelopment options: A new approach to estimating depreciation effects," Journal of Urban Economics, 67, 3, pp.362-377.

Clapp, J.M., Jou, J.B. and Lee, T.C. (2007), "Buy to scrape? The hedonic model with redevelopment options," paper presented at the Asian Real Estate Society Conference, Macau, 9-12 July 2007.

Clapp, J.M., Bardos, K.S. and Wong, S.K. (2012), "Empirical estimation of the option premium for residential redevelopment," Regional Science and Urban Economics, 42, 240-256.

Davis, O.A. and Whinston, A. (1962) "Externalities, welfare, and the theory of games," Journal of Political Economy, 70(3), 241-262.

Hendon, W.S. (1971), "The park as a determinant of property value," American Journal of 
Economics and Sociology, 30, pp.289-300.

Immergluck, D. (2009), "Large scale redevelopment initiatives, housing values, and gentrification: The case of the Atlanta Beltline," Urban Studies, 46, 1725-1747.

Lai, L.W.C., Chau, K.W., Yiu, C.Y. and Wong, S.K. (2007), "Measuring and interpreting the effects of a public sector-led urban renewal project on housing prices - an empirical study of a comprehensive development area zone developed upon 'taking' in Hong Kong," Environment and Planning B: Planning and Design, 34, pp.524-538.

Legislative Council (2009), Legislative council panel on development - Progress of work of the Urban Renewal Authority, Legislative Council: Hong Kong, available at: http://www.legco.gov.hk/yr08-09/english/panels/dev/papers/dev0623cb1-1947-3-e.pdf, accessed on Mar 2010.

Munneke, H.J. (1996), "Redevelopment decisions for commercial and industrial properties," Journal of Urban Economics, 39, 2, pp.229-253.

Nield, S. (1997) Hong Kong Land Law, Hong Kong: Longman.

Poon, L.C.L. (1978), "Railway externalities and residential property prices," Land Economics, 54, 2, pp.218-227.

Rosenthal, S.S. and Helsley R.W. (1994), "Redevelopment and the urban land price," Journal of Urban Economics, 35, 2, pp.182-200.

Rueter, F.H. (1973), "Externalities in urban property markets: An empirical test of the zoning ordinance of Pittsburgh," Journal of Law and Economics, 16, 2, pp.319-349.

Sirpal, R. (1994), "Empirical modeling of the relative impacts of various sizes of shopping centers on the values of surrounding residential properties," Journal of Real Estate Research, 9, 4, pp.487-505.

Tse, R.Y.C. (2001), "Impact of comprehensive development zoning on real estate development in Hong Kong," Land Use Policy, 18, pp.321-328.

Urban Renewal Authority (2008), Towards Urban Renewal 3.0. URA: Hong Kong.

Wong, S.K., Chau, K.W., Yau, Y. and Cheung, A.K.C. (2011) "Property price gradients: the vertical dimension," Journal of Housing and the Built Environment, 26, pp.33-45.

Yiu, C.Y. and Wong S.K. (2005), "Expectation effects of transportation improvement works on housing prices," Urban Studies, 42, 1, pp.113-125. 
Zabel, J.E. (2004) "The demand for housing services," Journal of Housing Economics, 13, 16-35. 


\section{List of Tables}

Table 1 Summary of the expected sign for the coefficients in Eq. (6a) and (6b)

\begin{tabular}{|c|c|c|c|}
\hline Description & Variable name & Expected sign & Remark \\
\hline Log building age & $\ln (A G E)$ & - & Control \\
\hline Log gross floor area of a unit & $\ln (G F A)$ & + & Control \\
\hline Log internal floor area of a unit & $\ln (\mathrm{IFA})$ & + & Control \\
\hline Log communal floor area of a unit & $\ln (C F A)$ & + & Control \\
\hline Log floor level of a unit & $\ln (F L R)$ & + & Control \\
\hline $\begin{array}{l}\text { A time dummy for the announcement of } \\
\text { an urban renewal project }\end{array}$ & $\mathrm{T}$ & $+/-$ & Control \\
\hline $\begin{array}{l}\text { T interacted with the site area of an urban } \\
\text { renewal project }\end{array}$ & T*SITE_SIZE & + & Prediction of $\mathrm{H} 1$ \\
\hline $\begin{array}{l}\text { T interacted with the commercial area of } \\
\text { an urban renewal project }\end{array}$ & T*COM_SIZE & + & Prediction of $\mathrm{H} 2$ \\
\hline $\mathrm{T}$ interacted with log building age & $T^{*} \ln (A G E)$ & - & Prediction of $\mathrm{H} 3$ \\
\hline $\begin{array}{l}\text { T interacted with building age and } \\
\text { commercial size }\end{array}$ & $T^{*} \ln (A G E) * D I S T$ & + & Prediction of $\mathrm{H} 3$ \\
\hline
\end{tabular}

Note: The dependent variable is $\ln ($ real sales price). 
Table 2 Descriptive statistics for the variables, from 1991 to 2011

\begin{tabular}{|c|c|c|c|c|c|c|c|c|}
\hline Description & $\begin{array}{l}\text { Variable } \\
\text { name }\end{array}$ & Mean (overall) & $\begin{array}{l}\text { Mean (before } \\
\text { urban renewal) }\end{array}$ & $\begin{array}{l}\text { Mean (after } \\
\text { urban renewal) }\end{array}$ & First quartile & Third quartile & $\begin{array}{l}\text { Standard } \\
\text { Deviation }\end{array}$ & $\begin{array}{l}\text { No. of } \\
\text { observations }\end{array}$ \\
\hline Real property price (HK\$Mil) & $\mathrm{RP}$ & 1.724 & 1.691 & 1.757 & 0.982 & 2.010 & 1.306 & 42,473 \\
\hline Building age (years) & AGE & 12.66 & 8.806 & 16.70 & 5.301 & 19.00 & 8.799 & 42,473 \\
\hline Gross floor area of a unit $\left(\mathrm{ft}^{2}\right)$ & GFA & 520.3 & 519.7 & 520.9 & 381.0 & 570.0 & 238.9 & 42,473 \\
\hline $\begin{array}{l}\text { Internal floor area of a unit } \\
\left(\mathrm{ft}^{2}\right)\end{array}$ & IFA & 406.6 & 407.6 & 405.7 & 307.0 & 445.0 & 192.0 & 29,341 \\
\hline $\begin{array}{l}\text { Communal floor area of a unit } \\
\left(\mathrm{ft}^{2}\right)\end{array}$ & CFA & 136.2 & 131.6 & 140.6 & 99.0 & 166.0 & 55.76 & 29,341 \\
\hline Floor level of a unit & FLR & 13.14 & 12.10 & 14.23 & 6.00 & 18.00 & 9.225 & 42,473 \\
\hline $\begin{array}{l}\text { Site area of an urban renewal } \\
\text { project }\left({ }^{\prime} 000 \mathrm{st}^{2}\right)\end{array}$ & SITE_SIZE & 30.94 & - & - & 14.90 & 38.06 & 20.80 & 42,473 \\
\hline $\begin{array}{l}\text { Commercial area of an urban } \\
\left.\text { renewal project ('000s } \mathrm{ft}^{2}\right)\end{array}$ & COM_SIZE & 23.25 & - & - & 12.36 & 37.04 & 13.40 & 42,473 \\
\hline $\begin{array}{l}\text { Distance from an urban } \\
\text { renewal project ('000s ft) }\end{array}$ & DIST & 0.416 & 0.418 & 0.415 & 0.316 & 0.531 & 0.150 & 42,473 \\
\hline
\end{tabular}


Table 3: Hedonic regression results

\begin{tabular}{|c|c|c|c|c|c|c|}
\hline & \multicolumn{3}{|l|}{ Eq. (6a) } & \multicolumn{3}{|l|}{ Eq. (6b) } \\
\hline & Coefficient & t-stat & & Coefficient & t-stat & \\
\hline Intercept & -6.114 & -157.8 & $*$ & -5.648 & -126.1 & * \\
\hline $\ln (A G E)$ & -0.072 & -61.51 & $*$ & -0.067 & -48.89 & * \\
\hline $\ln (G F A)$ & 1.097 & 224.5 & $*$ & - & - & \\
\hline $\ln (I F A)$ & - & - & & 0.969 & 163.5 & * \\
\hline $\ln (C F A)$ & - & - & & 0.110 & 23.64 & * \\
\hline $\ln (F L R)$ & 0.080 & 47.45 & * & 0.088 & 48.31 & * \\
\hline $\mathrm{T}$ & 0.129 & 16.79 & $*$ & 0.137 & 17.25 & * \\
\hline T*SITE_SIZE & $6.04 \mathrm{E}-04$ & 5.428 & * & $6.11 \mathrm{E}-04$ & 5.095 & * \\
\hline T*COM_SIZE & $9.41 \mathrm{E}-04$ & 5.149 & * & $1.25 \mathrm{E}-03$ & 6.702 & * \\
\hline $\mathrm{T}^{*} \ln (\mathrm{AGE})$ & -0.072 & -23.95 & * & -0.070 & -19.38 & * \\
\hline$T^{*} \operatorname{In}(A G E) * D I S T$ & 0.050 & 10.34 & $*$ & 0.025 & 4.345 & * \\
\hline Observations & 42,473 & & & 29,340 & & \\
\hline Adj. R2 & 0.826 & & & 0.830 & & \\
\hline
\end{tabular}

Note: The dependent variable is $\ln \left(\right.$ real sales price); ${ }^{*}$ means the coefficient is significant at the $1 \%$ level; coefficients of the location dummies are not shown here; both equations are estimated by OLS and the t-stat is based on White heteroskedasticity-consistent standard errors. 